\title{
Growth and Mineral constituents' variations in halophytic species under salinity
}

\author{
N. Silambarasan, S. Natarajan* \\ Department of Botany, Annamalai University, Annamalai Nagar, Chidambaram - 608 002, \\ Tamil Nadu, India \\ *E-mail address: s.natarajan20@yahoo.com
}

\begin{abstract}
The present investigation was made to study the effect of different concentrations of sodium chloride on the growth and mineral constituents in different parts of Clerodendron inerme. The plant and could survive a wide range of $100-1000 \mathrm{mM}$ of $\mathrm{NaCl}$. The upper limit for the survival of Clerodendron inerme was $500 \mathrm{mM} \mathrm{NaCl}$. However, favourable growth response by seedlings was confined to $200 \mathrm{mM} \mathrm{NaCl}$. The morphological parameters such as shoot and length, number of leaves, total leaf area, fresh and dry mass and mineral constituents such as sodium, potassium and calcium were assessed.
\end{abstract}

Keywords: Halophyte; Mineral content; Salinity

\section{INTRODUCTION}

World wide, more than 800 millon hectares of land are salt affected, and tolerance to this salinity differs greatly among plant species (Munns and Tester 2008). In India alone, about 30 millon hectares of coastal land is lying barren and uncultivable because of soil affected by salinity.

Stresses associated with temperature, salinity and drought single or in combination are likely to enhance the severity of problems in the coming decades (Claussen et al., 1985). Salt stress in soil or water is one of the major stresses especially in arid and semi-arid regions and can severely limit plant growth and productivity (Allakhverdier et al., 2000 and Koca et al., 2007).

Plant water stress is often the most prominent physiological response associated with increase in soil and / or water salinity (Munns 2002). Salt tolerance has been attributed as the primary factor in shaping vegetative structures, including biomass and species composition of coastal and estuarine wetlands (Bertness 1991; Pennings et al., 2001).

Controversial data exist regarding the question of whether halophytes require saline conditions for their existence and vigorous growth or merely tolerate them. One of the major factors in the salt tolerance is believed to be the existence of succulence. Halophytes survive salt concentration equal to or greater than that of seawater and possess physiological mechanisms that maintain lower water potential inside the cell than that in the soil (Ungar 1991). 
Salt tolerance in halophytes is brought about by a variety of physiological mechanisms and morphological adaptations. Adaptations of halophytes to the saline environment include high tolerance for the negative effect of salinity as well as positive reaction towards it. The compartmentation of ions in the vacuoles and accumulation of compatible solutes in the cytoplasm and presence of genes for salt tolerance confer salt resistance to halophytes (Gorham 1995).

The present study was made to investigate the salt tolerance of Clerodendron inerme.

\section{MATERIALS AND METHODS}

\section{1. Plant material}

The mature stem cuttings were collected from salt marshes in the mangrove area of Pichavaram, on the east coast of Tamil Nadu, India about 10km east of Annamalai University Campus.

\section{2. Growth conditions}

The stem cuttings of Clerodendron inerme ( $3 \mathrm{~cm}$ long with one node and 2 opposite leaves) were planted individually in polythene bags (7" $\times 5$ ") filled with homogenous mixture of garden soil containing red earth, sand and farm yard manure (1:2:1). The cuttings were irrigated with tap water and maintained in the Botanical garden, Annamalai University.

\section{3. Salt treatment and Experimental design}

One month old and well established cuttings were selected and treated with varying concentrations of $\mathrm{NaCl}(100-1000 \mathrm{mM})$. Above $500 \mathrm{mM} \mathrm{NaCl}$ concentrations the cuttings were not survived. The experimental plants treated with $\mathrm{NaCl}$ up to $500 \mathrm{mM}$ were alone maintained in the experimental site. The experimental yard was roofed with transparent polythene sheet at a height of $3 \mathrm{~m}$ from the ground in order to protect the plants from rain.

\section{4. Determination of growth and mineral constituents}

Samples were collected randomly on $60^{\text {th }}$ day after treatment. The seedlings were separated into leaves, stem and root and used for analysis. The morphological parameters such as shoot and root length, number of leaves, leaf area, fresh and dry mass were analyzed.

The minerals such as sodium, potassium were determined by the method of Willams and Twine (1960). The dried and ground tissues of $0.5 \mathrm{~g}$ were digested in $100 \mathrm{ml}$ Kjeldahl flasks using $10 \mathrm{ml}$ of concentrated nitric acid, $0.5 \mathrm{ml}$ of 60 per cent perchloric acid and $0.5 \mathrm{ml}$ of concentrated sulphuric acid. Digestion was continued until the nitric acid and perchloric acid were driven off. The inorganic residue was cooled and diluted with $15 \mathrm{ml}$ of distilled water and filtered through Whatmann No. 42 filter paper. The filtrate was made up to $50 \mathrm{ml}$ with distilled water. The filtrates were used for sodium and potassium estimation and a Flame Photometer (Systronics, India) were used for the purpose and standards were prepared with sodium chloride.

The calcium content was estimated by the method of Yoshida et al (1972). Two ml of the filtrate was mixed with two $\mathrm{ml}$ of $5 \%$ lanthanum oxide solution and diluted with ten $\mathrm{ml}$ of $1 \mathrm{~N}$ hydrochloric acid. The solution was fed into an Atomic Absorption Spectrophotometer (Perkin Elmer - 2280) at 211.9nm. Standard curve was prepared by using calcium chloride. 


\section{5. Statistical analyses}

Statistical analysis was performed using one way analysis of variance (ANOVA) followed by Duncan's Multiple Range Test $(P$ values $\leq 0.05)$ with the help of SPPS 20 software package. Means and standard deviation were calculated from 5 replication.

\section{RESULT}

\section{1. Shoot and Root length}

The observations on the effect of different concentrations of $\mathrm{NaCl}$ salinity on the shoot and root length on the $60^{\text {th }}$ day after saline treatment is presented in Figure 1. The shoot and root length increased with increasing $200 \mathrm{mM} \mathrm{NaCl}$ in Clerodendron inerme and thereafter it gradually declined. The maximum increase shoot length was $17.6000 \pm 0.2000$ and root length was $19.4200 \pm 0.8602$ Clerodendron inerme over that of control.

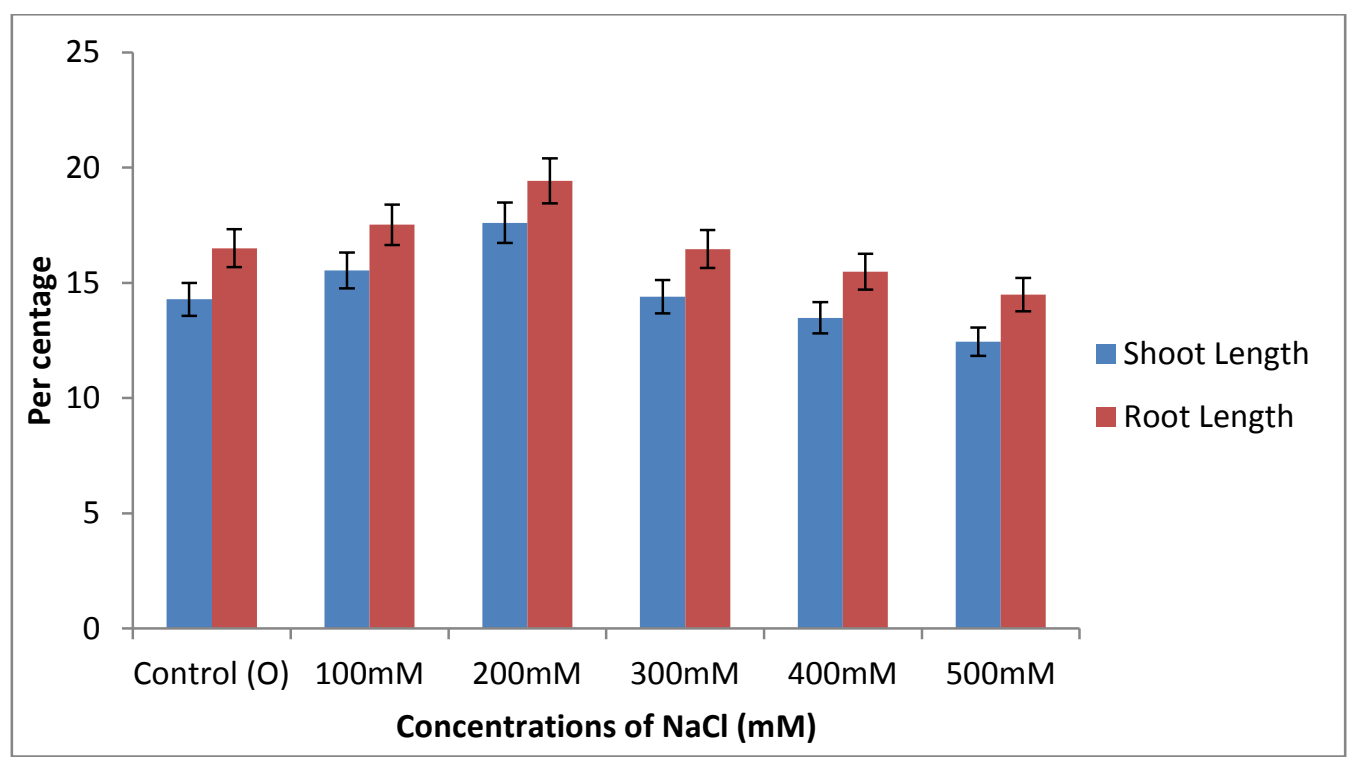

Fig. 1. Effect of $\mathrm{NaCl}$ on shoot length $\left(\mathrm{cm} \mathrm{plant}^{-1}\right)$ and root length $\left(\mathrm{cm} \mathrm{plant}^{-1}\right)$ of Clerodendron inerme on $60^{\text {th }}$ day after salt treatment.

\section{2. Leaf area and Number of leaves}

The result on the effect of $\mathrm{NaCl}$ on the number of leaves per plant is given in Figure 2. The maximum increase in number of leaves and leaf area was observed on the $60^{\text {th }}$ day at 200 $\mathrm{mM}$ Clerodendron inerme. In the optimum concentration, the calculated number of leaves was $26.2000 \pm 0.80000$ and leaf area was $31.6700 \pm 0.04506$ when compared to that of control. Beyond this optimum concentration, there was a gradual decrease in the number of leaves and leaf area. 


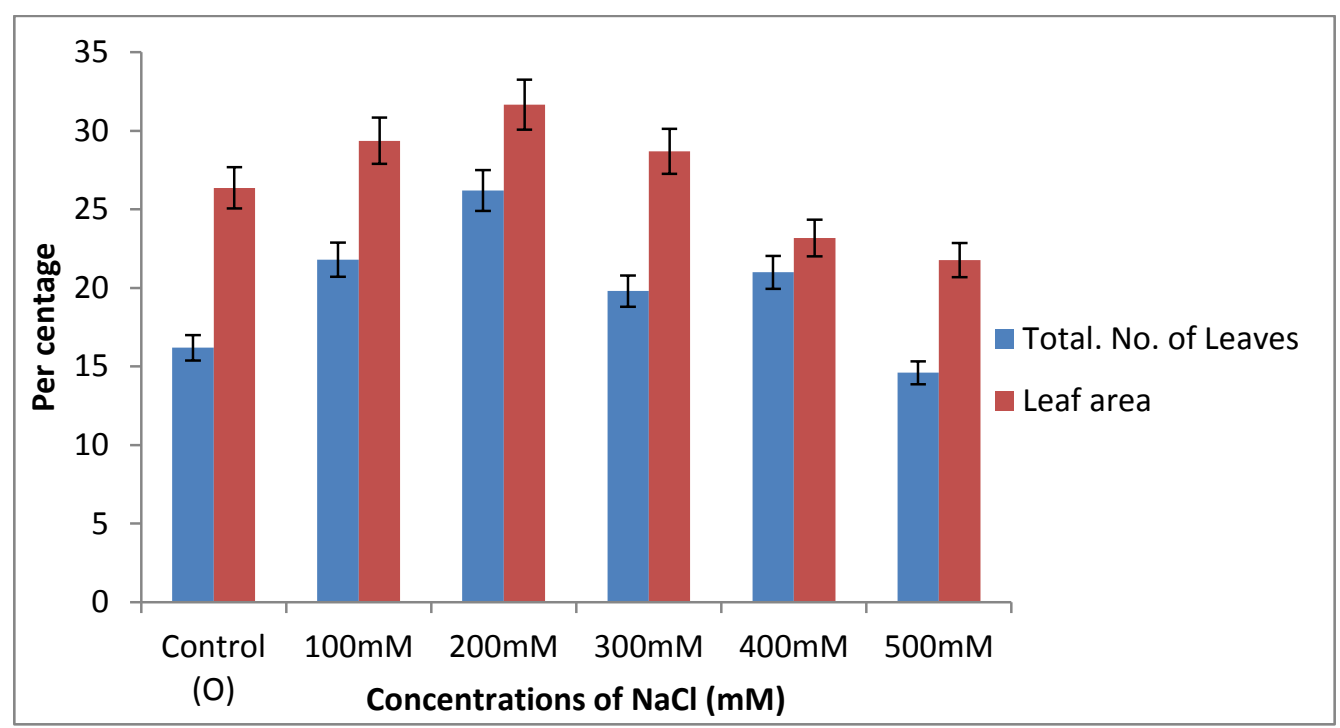

Fig. 2. Effect of $\mathrm{NaCl}$ on total no. of leaves $\left(\right.$ plant $\left.^{-1}\right)$ and leaf area $\left(\mathrm{cm}^{2}\right.$ plant $\left.^{-1}\right)$ of Clerodendron inerme on $60^{\text {th }}$ day after salt treatment.

\section{3. Fresh Mass}

The results on the effect of $\mathrm{NaCl}$ on the fresh mass of leaf stem and root on the 60th day after saline treatment are given in Figure 3. An increase in the fresh mass of tissues was observed up to $200 \mathrm{mM} \mathrm{NaCl}$ in Clerodendron inerme on the $60^{\text {th }}$ sampling days. Concentrations of $\mathrm{NaCl}$ beyond $200 \mathrm{mM}$ had reduced the fresh mass in all the three tissues. The maximum increase in the fresh mass of leaf, stem and root was $4.7160 \pm 0.06615,3.2029$ \pm 0.02311 and $2.0940 \pm 0.2502$ over that of control.

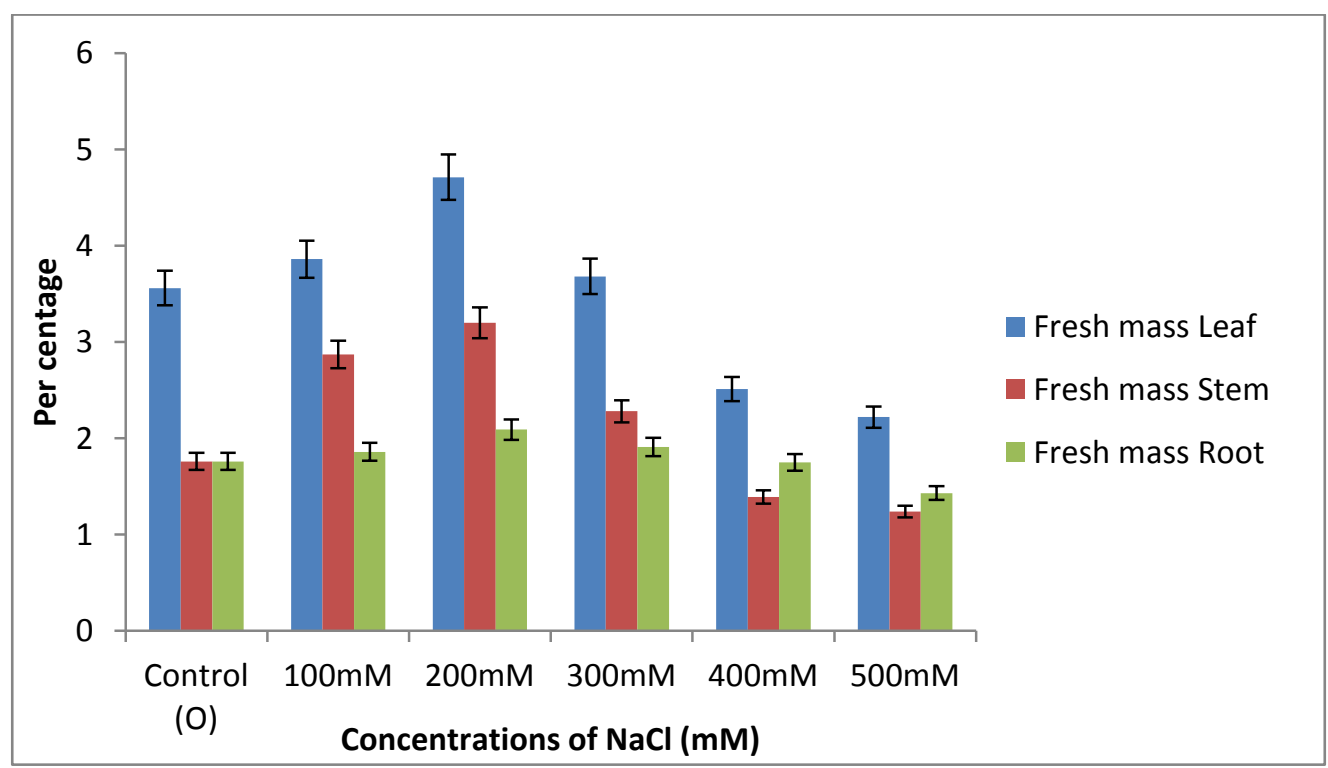

Fig. 3. Effect of $\mathrm{NaCl}$ on fresh mass of leaf, stem and root $\left(\mathrm{g} \mathrm{plant}^{-1}\right)$ of Clerodendron inerme on $60^{\text {th }}$ day after salt treatment. 


\section{4. Dry Mass}

The results on the effect of $\mathrm{NaCl}$ on the dry mass of leaf stem and root on the $60^{\text {th }}$ day of saline treatment are presented in Figure 4. The dry mass of the three tissues increased with increasing $\mathrm{NaCl}$ up to $200 \mathrm{mM}$ Clerodendron inerme and thereafter it decreased. The maximum increase in dry mass of leaf, stem and root was $0.56600 \pm 0.0241,0.4400 \pm 0.02236$ and $0.3520 \pm 0.0960$ over that of control.

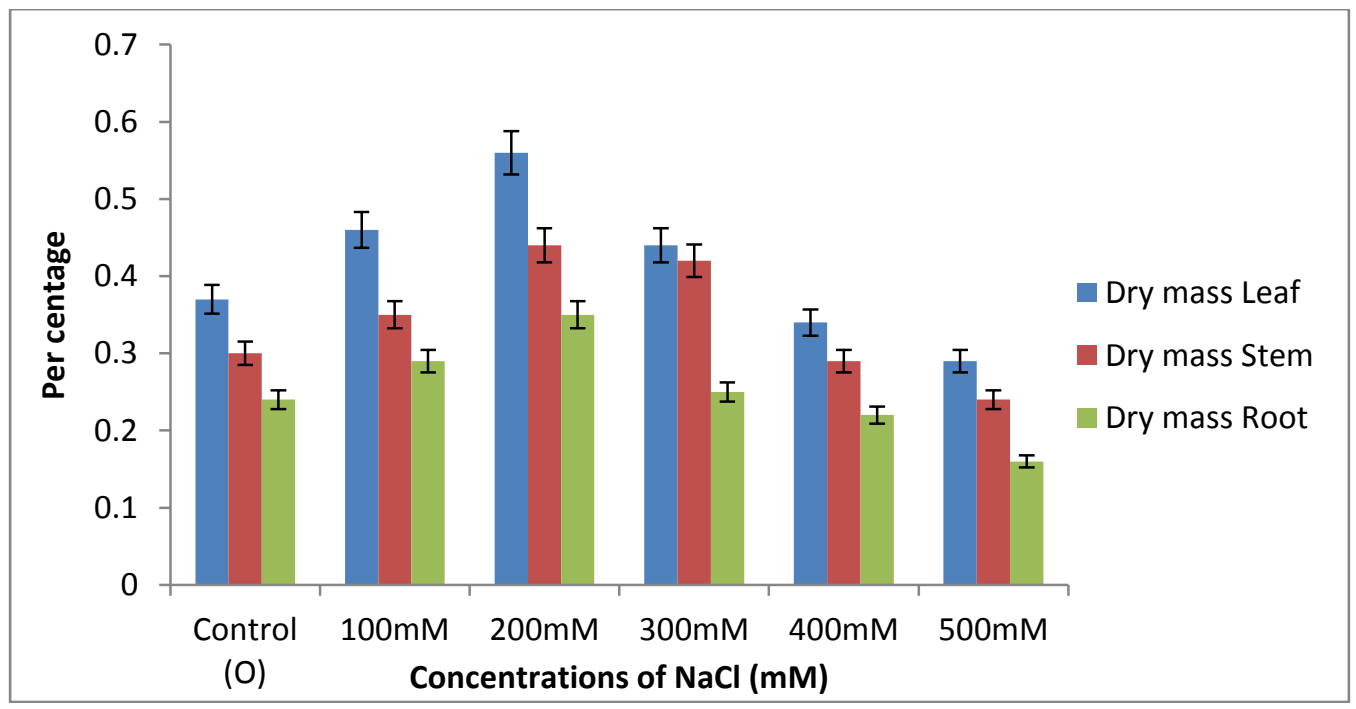

Fig. 4. Effect of $\mathrm{NaCl}$ on dry mass of leaf, stem and root $\left(\mathrm{g}_{\text {plant }}{ }^{-1}\right)$ of Clerodendron inerme on $60^{\text {th }}$ day after salt treatment.

\section{5. Sodium}

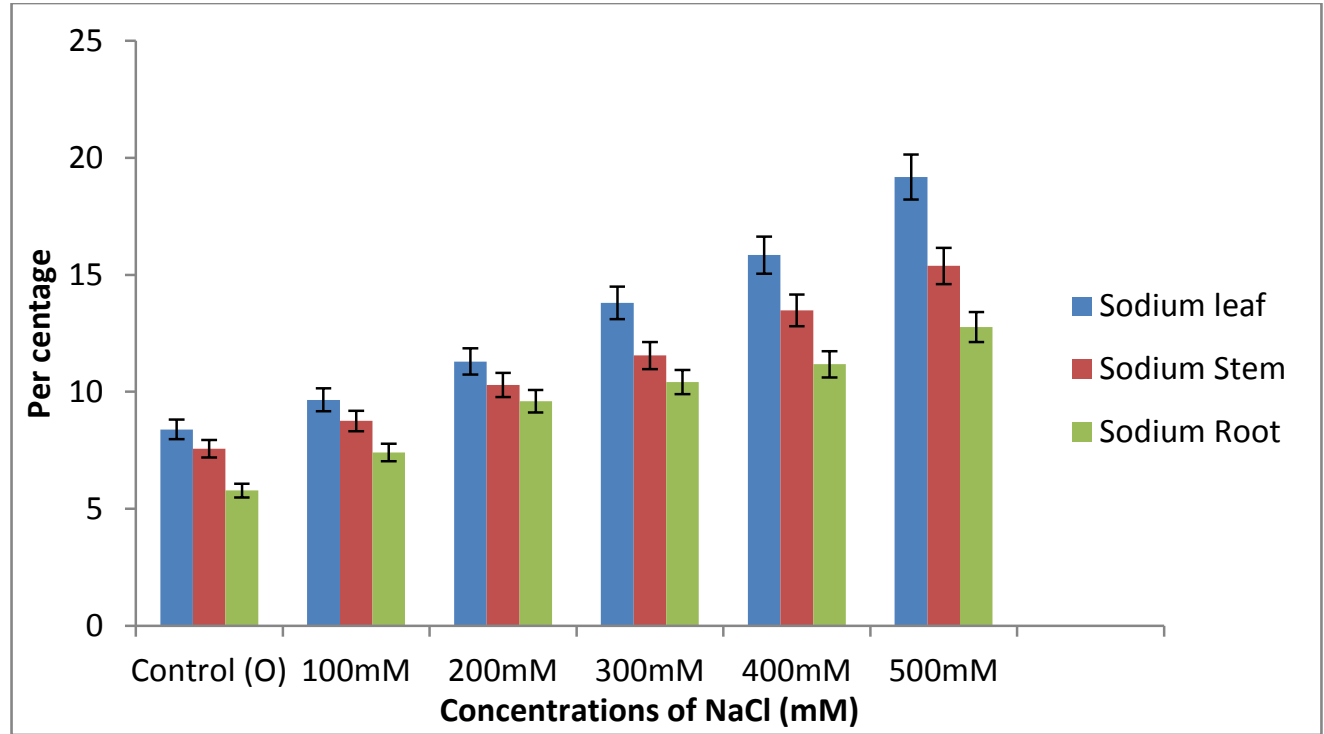

Fig. 5. Effect of $\mathrm{NaCl}$ on sodium content (mg/g dr. wt.) of the leaf, stem and root of Clerodendron inerme on $60^{\text {th }}$ day after salt treatment. 
The results on the effect of $\mathrm{NaCl}$ salinity on the sodium content of leaf, stem and root of Clerodendron inerme are presented in Figure 5. There was a considerable increase in sodium content with increasing concentration of $\mathrm{NaCl}$ salinity up to extreme levels in Clerodendron inerme. Of the three tissues, the leaf accumulated more sodium than the stem and root.

\section{6. Potassium}

The results on the effect of $\mathrm{NaCl}$ salinity on the potassium content of leaf, stem and root of Clerodendron inerme are presented in Figure 6. There was a steady increase in the potassium content with increasing concentrations of $\mathrm{NaCl}$ in the leaf, stem and root tissues on $60^{\text {th }}$ the sampling days. The accumulation of potassium ions increased up to the extreme level $500 \mathrm{mM} \mathrm{NaCl}$ in Clerodendron inerme than that of control.

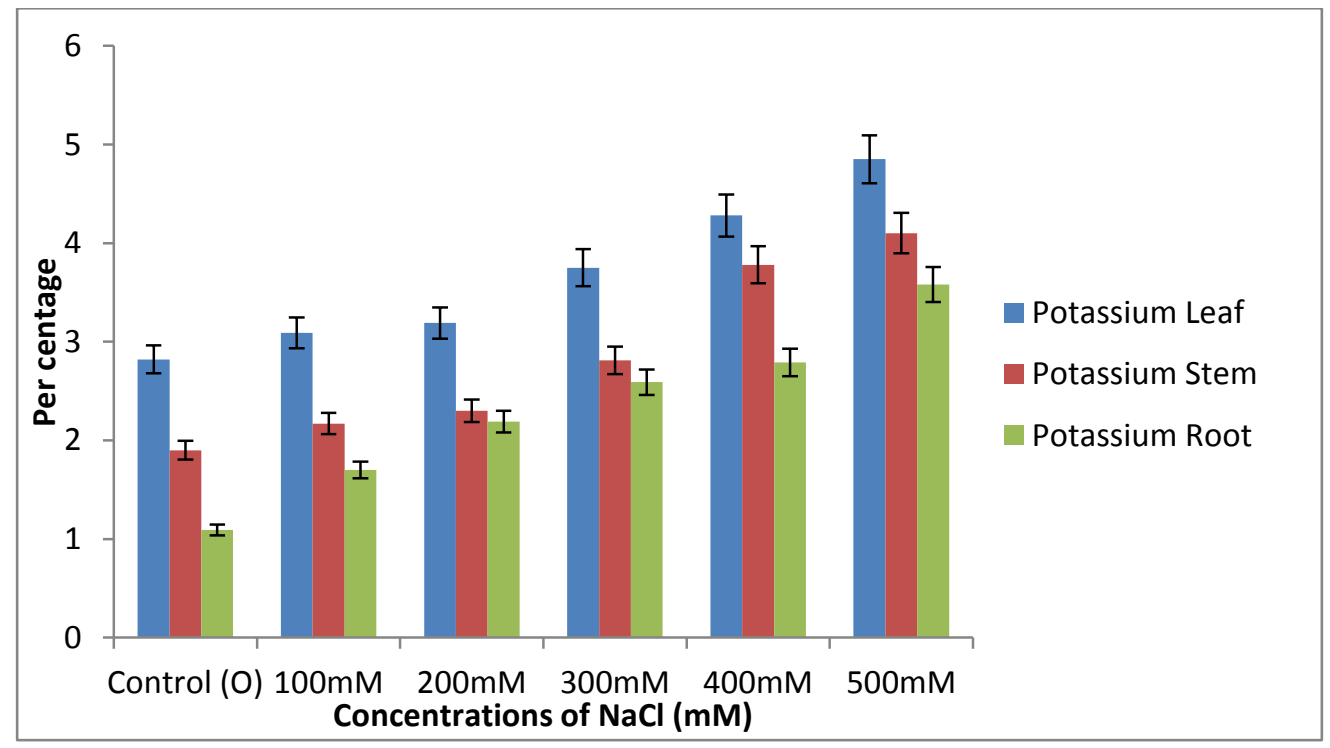

Fig. 6. Effect of $\mathrm{NaCl}$ on potassium content ( $\mathrm{mg} / \mathrm{g}$ dr. wt.) of the leaf, stem and root of Clerodendron inerme on $60^{\text {th }}$ day after salt treatment.

\section{7. Calcium}

The results on the effect of different concentrations of $\mathrm{NaCl}$ on calcium content in the leaf, stem and root are given in Figure 7. The calcium content of all the three tissues increased with increasing salinity the optimum concentration in Clerodendron inerme and at higher concentrations the calcium content had decreased gradually. The leaf calcium was always higher than that of stem and root. 


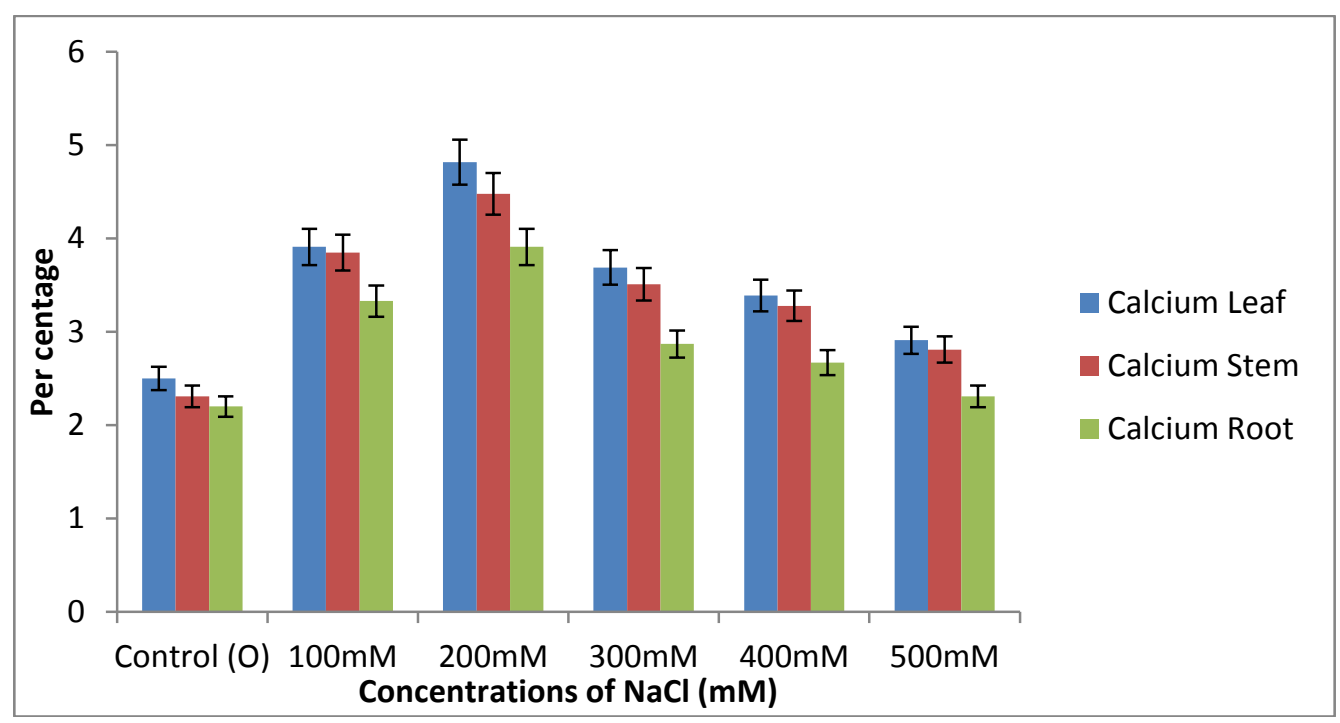

Fig. 7. Effect of $\mathrm{NaCl}$ on calcium content (mg/g dr. wt.) of the leaf, stem and root of Clerodendron inerme on $60^{\text {th }}$ day after salt treatment.

\section{DISCUSSION}

In the present study, $\mathrm{NaCl}$ had favorably affected the growth of the seedlings of Clerodendron inerme by increasing shoot length and root length with increasing salinity. The upper limit for survival of seedlings to $\mathrm{NaCl}$ salinity was $500 \mathrm{mM}$. At the optimum concentration, $\mathrm{NaCl}$ had approximately similar effect on the growth of the seedlings. The data on growth response to revealed a depressed growth both in the absence of salt and at high salinity of $\mathrm{NaCl}$. A stimulation of growth in response to moderate levels of $\mathrm{NaCl}$ salinity has been reported in several halophytes. Sesuvium portulacastrum survived up to $900 \mathrm{mM}$ $\mathrm{NaCl}$, but produced favorable growth at $600 \mathrm{mM} \mathrm{NaCl}$ (Venkatesalu et al., 1994). Salicornia europaea and Arthocnemum australiasicum survived double the strength of seawater (McMillan, 1974). A positive growth response to moderate salinities has been reported in the mangrove species Avicennia marina (Downton, 1982; Clough, 1984) and Aegiceras corniculatum (Ball and Forquhar, 1984).

The decline in leaf number at high concentrations was due to the leaf fall because of ageing. Salinity has been shown to be one of the external factors that influence the process of senescence and the consequent shedding of leaves (Pool et al., 1975). The number of leaves reduced only at the highest salt concentration but the dead leaves were increased with salinity as a mean of protecting the young growing leaves to toxic levels of the salts as well as offloading the plants of excess salts (Wahome, 2001). The increase in the leaf area could be due to the increase in the volume of mesophyll cells due to increase in water content of the leaves and increase in succulence. The external $\mathrm{NaCl}$ stimulated the leaf area at optimum level of seawater in Rhizophora mangle (Hwang and Chen, 1995). Salinity has been reported to promote succulence in several plant species viz., Plantago maritima (Flanagan and Jefferies, 1988) and Sesuvium portulacastrum (Venkatesalu and Chellappan, 1993).

Sodium chloride salinity increased the fresh weight of leaf, stem and root with increasing salinity up to the optimum concentrations. The increase in fresh weight of the leaf tissue can be attributed to the increase in leaf thickness (Clipson, 1987) and the accumulation 
of ions and water in the tissues (Khan et al., 2005; Lee et al., 2005). Also, the fresh weight increase could be largely attributed to cell enlargement by water absorption, cell vacuolation and turgor driven wall expansion (Ayala and O'Leary, 1995). The increase in water content could be good reason for tissue succulence (Storey and Wyn Jones, 1979) and salinity promoted succulence in a number of halophytes (Ayala and O' Leary, 1995). The dry weight increase could be attributed to the accumulation of inorganic salts and organic matter in the plant tissues. In the dicotyledonous halophytes, it was observed that $\mathrm{Na}^{+}$and $\mathrm{Cl}^{-}$ions were $30-50 \%$ of the dry weight (Flowers et al., 1986). The results of the present study also indicated the obligate requirement of optimum concentration of $\mathrm{NaCl}$ for cell growth and increase in dry weight. The accumulation of salt has a positive function. Similar observations have been observed in certain other halophytes such as, Chenopodium quinoa (Prado et al., 2000), Kandelia candel (Hwang and Chen, 2001), Heleochola setulosa (Joshi et al., 2002) and Aegiceras corniculatum (Manikandan and Venkatesan, 2004).

The $\mathrm{NaCl}$ treatment increased the sodium content more in the leaf tissues than in the stem and root tissues with increasing of $\mathrm{NaCl}$ salinity up to extreme levels in Clerodendron inerme and $S$. portulacstrum on 60 th day the sampling days. Increased availability of sodium in the soil influenced a proportional increase in the uptake of sodium by the seedlings. Many salt tolerant organisms accumulate higher intracellular ion concentration than their nontolerant counter parts. Different halophytes have been reported to differ in the rate of accumulation of sodium in their cells and differences are mainly due to difference in the mode of salt regulation. Some vascular halophytes accumulate high levels of sodium and other salts in their above ground tissue while others did not (Gorham et al., 1987).

The accumulation of high sodium content in halophytes in the present study are in agreement with those of several other accumulating type of halophytes such as Suaeda maritima (Clipson, 1987) Suaeda nudiflora (Joshi and Iyengar, 1987), Sesuvium portulacastrum (Venkatesalu et al., 1994), Ipomoea pes-caprae (Venkatesan et al., 1997) and Suaeda fruticosa (Khan et al., 2000). The concentration of $\mathrm{Na}^{+}$in the leaves of salinized plants was approximately 40-fold higher than that measured in non-salinized controls (Maggio et al., 2003). While sodium is not considered to be a plant nutrient, it is essential for halophytes to accumulate salts to maintain turgor pressure and growth (Borox, 2002), for survival in high salt (Wong et al., 2006).

Potassium is a macronutrient that is required in the plant cell in high concentrations. It plays essential roles in growth regulation, osmotic adjustment and regulation of stomata opening (Brownell, 1979). In all plant cells, cytosolic $\mathrm{K}^{+}$concentrations must remain relatively high (Leigh and Wyn Jones, 1984). Chloroplasts and mitochondria also contain relatively high levels of potassium. On the other hand, $\mathrm{Na}^{+}$concentrations must be maintained at low levels in the cytoplasm and in the organelles (Wang et al., 2004). The increasing salinity decreased the potassium contents of some halophytes such as Suaeda maritima (Clipson, 1987); Rhizophora mangle and Laguncularia recimosa (Medina et al., 1995). Potassium uptake was adversely affected by $\mathrm{NaCl}$ treatment in Hordeum vulgare and Salicornia europea (Demiral et al., 2005; Ushakova et al., 2005).

Increase in calcium content can be attributed to the overall performance of metabolic activity of plants treated with the salts up to the optimum concentrations. Calcium also serves to protect membrane damage and it plays a key role in the selective transport of potassium in the presence of excess of sodium, and thereby making a plant more salt tolerant (Epstein, 1980). Increasing external calcium salinity decreased the $\mathrm{Ca}^{2+}$ contents in Aegiceras corniculatum (Shindle and Bhosale, 1985); Rhizophora mucronata and Avicennia officinalis (Bhosale and Malik, 1991); Allenrolfea occidentalis (Bilquees et al., 2000) and Atriplex 
griffithii (Khan and Ungar, 2000). In Suaeda nudiflora, salinity caused no change in $\mathrm{Ca}^{2+}$ content (Joshi and Iyengar, 1987).

\section{CONCLUSION}

In conclusion, the observation on $\mathrm{NaCl}$ treated Clerodendron inerme plant suggested that growth and minerals constituent's increased up to optimal level of salinity and at higher salinity declined gradually.

\section{ACKNOWLEDGEMENT}

The authors are grateful thanks to Head, Department of Botany, Asnnamalai University, Annamalainagar for providing necessary facilities to carry out this work and University Grants Commission. Grant F. No. 41454/2012 (SR) Dated: 16-07-2012 for funding the project.

\section{Reference}

[1] S.I. Allakhaverdiev, A. Skamoto, Y. Nishiyama, M. Inaba, N. Murata, Plant Physiol 123(2000). Ionic and osmotic effects of NaCl-induced inactivation of photosystems I and II in synechococcus sp Plant Physiol, 123: 1047-1056.

[2] Ayala, F. and J.W. O'Leary, 1995. Growth and physiology of Salicornia bigelovii Torr. at sub optimal salinity. Ind. J. Plant Sci, 156: 197-205.

[3] Ball, M.C. and G.D. Farquhar, 1984. Photosynthetic and stomatal responses of two mangrove species, Aegiceras corniculatum and Avicennia marina to long term salinity and humidity conditions. Plant Physiol, 62: 889-893.

[4] Bhosale, L.J. and N.G. Malik, 1991. Strategies of seed germination in mangroves Proc. In turn Seed Symposium. Pp. 201-205.

[5] Bilquees, G., D.J. Weber and M.A. Khan, 2000. Effect of salinity and planting density and physiological responses of Allenrolfea occidentalis. Western north American Naturalist. 60: 188-197.

[6] Borax, C. 2002. Boran from the USA. Website www.borax.com/ agriculture.

[7] Brownell, P.F. 1979. Sodium as an essential micronutrient element for plants and its possible role in metabolism. Adv. Bot. Res, 7: 117-224.

[8] Clipson, N.J.W. 1987. Salt tolerance in the halophyte Suaeda maritima L. Dum. Growth, ion and water relations and gas exchange in response to altered salinity. J. Exp. Bot, 38: 1996-2004.

[9] Clough, B.F. 1984. Growth and salt balance of the mangroves Avicennia marina (Forsk). Vierh and Rhizophora stylosa Griff. In relation to salinity. Aust. J. Plant Physiol, 11: 419-430.

[10] Demirnal, M.A., M. Aydin, and A. Yorulmaz, 2005. Effect of salinity on growth chemical composition and antioxidative enzyme activity of two malting barley (Hordeum vulgare L.) cultivars. Turk. J. Biol, 29: 117-123. 
[11] Downton, W.J.S. 1982. Growth and osmotic relations of the mangrove Avicennia marina as influenced by salinity. Aust. J. Biol. Sci. pp. 519-528.

[12] Epstein, E. 1980. Impact of plant productivity for food, chemicals and energy. In: Genetic Engineering of osmoregualation. pp. 7-21.

[13] Flanagan, L.B. and R.L. Jefferies. 1988. Stomatal limitation of phytosynthesis and reduced growth of the halophyte Plantago maritima (L.) at high salinity. Plant Cell and Environ, 11: 239-246.

[14] Flowers, T.J., S.A. Flower and H. Greenway, 1986. Effect of sodium chloride on tobacco plants. Plant Cell and Environment. 9: 645-651.

[15] Gorham, J., C. Hardy, R.G. Wyn Jones, L.R. Joppa and C.N. Law, 1987. Chromosomal location of the $\mathrm{K}+/ \mathrm{Na}+$ discriminating characters in the $\mathrm{D}$ Genome of wheat. Theae Appl. Genet, 74: 584-588.

[16] Hwang, Y.H. and S.H. Chen, 1995. Anatomical responses in Kandelia candel (L.) Deuce. Seedlings growing in the presence of different concentrations of NaCl. Bot. Bul. Acad. Sci, 36: 181-188.

[17] Hwang, Y.H. and S.H. Chen, 2001. Effects of ammonium phosphate and salinity on growth, gas exchange characteristics and ionic contents of seedling of mangrove Kandelia candel (L.) Druce. Bot. Bull. Acad. Sin, 42: 131-139.

[18] Joshi, A.J. and E.R.R. Iyengar, 1987. Effects of seawater salinity on free amino acids and mineral ions are Suaeda nudiflora Moq. Proc. Indian. Acad. Sci, 97: 309-314.

[19] Joshi, A.J., A. Sagar Kumar and H. Heriglajia, 2002. Effects of sea water on germination, growth, accumulation of organic components and inorganic ions in halophytic grass Heleochola setulosa (TRIN). Blattet Mccann Indian J. Plant Physiol, 7: 26-30.

[20] Khan, M.A. and I.A. Ungar, 2000. Alleviation of innate and salinity induced dormancy in Atriplex griffithii. Moq. Var. Stoksiboiss. Seed Sciences and Technology. 28: 29-37.

[21] Khan, M.A., I.A. Ungar and A.M. Showalter, 2000. The effect of salinity on the growth water status and ion content of a leaf succulent perennial halophyte Suaeda fruticosa. J. Arid Environ, 45: 73-84.

[22] Khan, M.A., I.A. Ungar and A.M. Showalter, 2005. Salt stimulation and tolerance in an inter tidal stem - succulent halophyte. J. Plant Nutr, 28: 1365-1374.

[23] Lee, G., V. Carrow and A. Duncan, 2005. Growth and water relation responses to salinity stress in halophytic sea shore Paspalum ecotypes, Sci. Hort, 104: 221-236.

[24] Leigh, R. A. and R. G. Wyn Jones, 1984. A hypothesis relating critical potassium concentration for growth to the distribution and functions of this ion in the plant cell. New Physiol, 97: 1-13.

[25] Maggio, A., M.P. Reddy and R.J. Joly, 2003. Leaf gas exchange and solute accumulation in the halophyte Salvadora persica grown at moderate salinity. Environ. Exp. Bot, 44: 31-38.

[26] Manikandan, T. and A. Venkatesan, 2004. Influence on $\mathrm{NaCl}$ on growth, organic constituents and certain antioxidant enzymes of Aegiceras corniculatum. Blanco. Geobios.31: 30-33. 
[27] McMillan, C. 1974. Salt tolerance of mangroves and submer ged aquatic plants. Reimold, R.J. and W.H. Queen (eds.) pp. 379-390. Academic press, New York.

[28] Medina. E., A.E. Lugo and A. Novelo, 1995. Mineral content of foliar tissue of mangrove species of the some common lagoon (Vera cruz, Mexico) and its relation with salinity N. Biotropica, 27: 317-323.

[29] Pool, D.J., A.E. Lugo and S.C. Snedaker, 1975. Litter production in mangrove forest of Southern Florida and Puerto Rico. In: Proc. Int. Symp. Biol. and Management of mangroves. Vol. I. Walsh, G.E. S.C. Snedaker and H.J. Teas. (eds.), pp. 213-237. Int. Food. Agri. Sci, Univ. Florida, Gainesville.

[30] Prado, F. E., C. Boern, M. Gallardo and H. J. A. Gonzalez, 2000. Effect of NaCl on germination, growth and soluble sugar content in Chenopodium quinoa, wild seeds. Bot. Acad Sci, 41: 27-34.

[31] Shindle, L. S. and L. J. Bhosale, 1985. Studies on salt tolerance in Aegiceras corniculatum (L.) Blanco and Sesuvium portulacastrum (L). The mangroves: Proc. Nat. Symp. Biol, Util. Cons. Mangroves. 300-304. Shivaji University, Kolhapur.

[32] Storey, R. and R.G. Wyn Jones, 1979. Responses of Atriplex spongiosa and Suaeda monoica to salinity. Plant Physiol, 63: 156-162.

[33] Ushakova, S. A., N.P. Kovalera, I.V. Gribovskaya, V.A. Ddgushev and N.A. Tikhomira, 2005. Effect of $\mathrm{NaCl}$ concentration on productivity and mineral composition of Salicornia europea as a potential crop for utilization $\mathrm{NaCl}$ in LSS. $A d v$. Space Res, 36:1349-53.

[34] Venkatesalu, V. and K.P. Chellappan, 1993. Photosynthetic characteristics of Sesuvium portulacastrum (L.) under salt stress. Photosynthetica. 28: 313-316.

[35] Venkatesalu, V., R. Rajkumar and K.P. Chellappan, 1994. Growth and mineral distribution of Sesuvium portulacastrum L. a salt marsh halophyte, under

[36] Venkatesan, A., K.P. Chellappan and V. Venkatesalu, 1997. Salinity stress on mineral nutrition and growth of Ipomoea pes-caprae, sweet. Geobios. 24: 112-118.

[37] Wahome, P.K. 2001. Mechanism of salt stress tolerance in two rose root stocks: Rosa chinensis "Major" and Rosa robiginosa. Sci. Hortic, 87: 207-216.

[38] Wang, B., U. Luttge and R. Ratajczak, 2004. Specific regulation of SOD isoforms by $\mathrm{NaCl}$ and osmotic stress in leaves of the $\mathrm{C}_{3}$ halophyte Suaeda salsa (L.). J. Plant Physiol, 161: 285-293.

[39] Williams, C.H. and V.Twine, 1960. In: Modern methods of plant analysis, Peach, K. and M.V. Tracey (eds.) pp 3-5. Springer-Verlag - Berlin.

[40] Wong, C.E., Y. Li, A. Labbe, D. Guevara, P. Nuin and B. Whitty, 2006. Transcriptional profiling implicates novel interactions between abiotic stress and hormonal responses in Thellungiella, a close relative of Arabidopsis. Plant Physiol, 140: 1437-50.

[41] Yoshida, S., D.A. Forno, J. Cock and K.A. Gomez, 1972. Laboratory manual for physiological studies of rice, 1221, Philippines. 